\title{
ウェーブレット変換を用いた半導体ベアチップの クラック欠陷検出
}

\author{
斉藤 文 彦**
}

A Method to Detect Crack Defects on Semiconductor Bare Chip Using Wavelet Transform

Fumihiko SAITOH

\begin{abstract}
This paper proposes a method to detect crack defects that occur on edges of a semiconductor bare chip by using image processing and the wavelet transform. The one-dimensional profile that represents the unevenness condition on a side of a semiconductor bare chip is measured on the basis of the locations of four corners of the chip. Next, the wavelet transformed is executed to the profile. And, the crack defects are detected through the thresholding method to the amplitude and the frequency in the wavelet-transformed image. Experimental results show that the detectable rate of the crack defects reached $100 \%$ although a little overkill occurred.
\end{abstract}

Key words: semiconductor bare chip, visual inspection, wavelet transform, image processing

\section{1. 緒专}

ノートパソコン等の普及に伴い, 電子部品実装の高密度化が 進んでいる. 特に, 半導体デバイスに関しては, フリップチッ プ実装と呼ばれる，ベアチップを基板表面に直接実装する方法 が採用されつつあるり。フリップチップ赛装では, べアチップ搭 載装置を用い，チップ底面に形成されているバンプと基板表面 の接続端子間の位直決めを行った後, チップが基板上に実装さ れる2!.この工程では, プローブがチップ上面に接触して圧力が 加えられるため, チップに傷や欠けが存在する場合, 機械的ダ メージを与える可能性がある. ベアチップに発生する甥や欠け の中で最も代表的なものは，チップのエッジ部分に発生するク ラックである. クラックは，図１に示すように，ウエハからべ

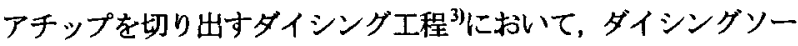
と呼ばれるダイヤモンドの微粒を貼り付けた円形カッタの摩耗 状態の変化等によって発生する.

本論文では，半導体べアチップのエッジ部分に発生するクラ ックを画像処理によって検出する手法を提案する. クラックは, その性質上，欠け部分の幅が細くかつ梁い方が重要性の高い欠 陷となる.一方, チップのエッジ部分は, ダイシングの結果, 完全な直線状とはならず，多くの微細な凹凸が発生する，信頼 性の高いクラック検出を実現するためには，これらエッジ部分 の凹凸の妨害を受けにくい検出手法が必要となる：ここでは， チップのエッジ部分の形状を 1 次元データと見なし, ウェーブ

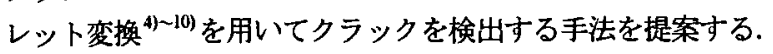

\section{2. ベアチップのクラック欠宿の特徽}

ダイシング工程では，ウエハを直線状に切断し，個々のベア チップとして切り出ず). ダイシング時には，チップ内部に機械 的久陥が入らないように，ダイシングソーのブレード圧力やカ ッティングスピードが制御される. ベアチップのエッジ部分は

\footnotetext{
*原稿受付 平成 12 年 1 月 4 日

*正会負 岐帛大学工学部 (岥阜市柳戸 1-1)
}

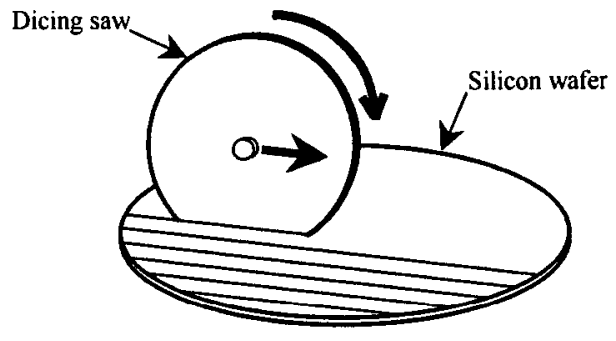

Fig.1 Dicing process for silicon wafer

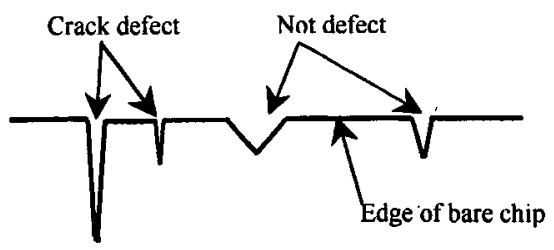

Fig.2 Crack defect on edge of bare chip

完全な直線となることが望ましいが，ダイシングソーの摩耗や 切り糟等の影響によって, 微小な凹凸が発生する. クラックは,

図 2 に示寸ように，通常の凹凸部分と比較して鋭利なくさび形 をしている．欠けの幅が広かったり，くさびの傾斜が緩い場合 は，欠宿とは認められない. しかし，欠けが比較的浅くても， 幅が狭い場合は，チップ搭載工程においてチップがダメージを 受ける可能性が高いことから，欠陥と判定される. 現在, クラ ックの検査は目視に頼っており，自動化が望まれている.

ところで，クラックは 2 次元的な形状を持つ欠陷なので, 従 来の画像処理手法を用いた検出方法が考えられる. 具体的には, 2 值化したチップのエッジ部分に対して，局所的な膨張と縮退処 理 ${ }^{1112)}$ を練り返すことによって欠け部分を抽出し，次に，形状特 徵を解析することによって，クラックを特定する方法である. しかし，この方法では，複数の欠けが隣接する場合，各々の分 離が困難となる．また，欠け部分の形状を詳細に解析するため には，光学的に抾大した複数の画像が必要と考えられる. 本手 


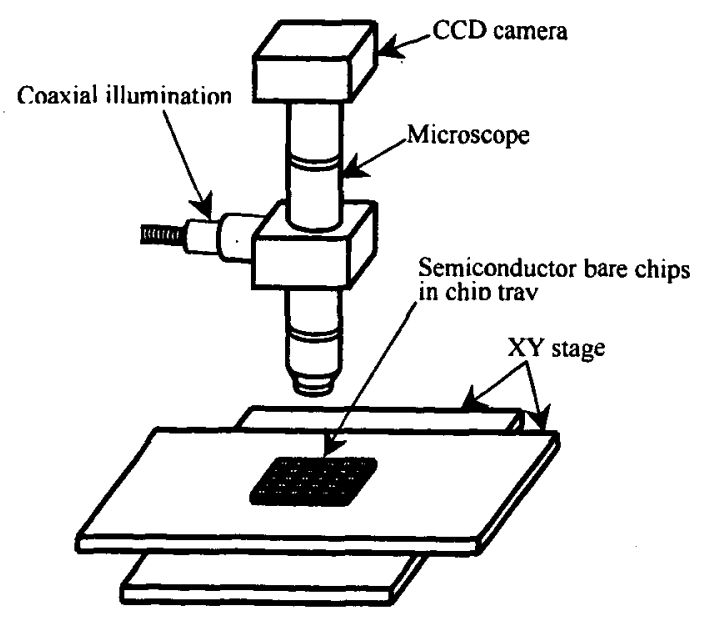

Fig.3 Configuration of the bare chip inspection system

法では, ベアチップ全体を視野とする 1 枚の画像を用いてクラ ックの検出を行う．従って，各チップを検查する間，XY ステー ジの移動が不要となり，検査の高速化が期待できる.

\section{3. 険査システム}

図 3 にベアチップ唡査システムの構成を示す,ベアチップは, 一辺が $4.7 \mathrm{~mm}$ の正方形である. 数十個のベアチップが尃用の卜 レ一内に 2 次元的に配置されている.トレ一はXY ステージ上に 乗せられており，鉛直上に位置するカメラによって，各チップ の上面が順次撮影される．同軸落射照明によって，鏡面に近い チップ上面では照明光が光軸方向に反射され，一方，欠けや傷 では照明光が乱反射するため，比較的良好なコントラストを持 つ濃淡画像が得られる. 画像サイズは $512 \times 512$ 画素である.

なお, カメラに対する各チップの姿勢は, $\mathrm{xy}$ 方向で士15 画 素, 傾きで士4 $4^{\circ}$ 程度の範囲で位置ずれが発生する. 従って, ク ラックの検出に先立って，チップの姿勢を計測する必要がある.

\section{4. クラック検出処理}

ベアチップの各辺の円凸を 1 次元のプロファイルと考えると, クラックは, プロファイルの中で特にくさび形が鋭利な部分と 言える. すなわち，1 次元の波形の中で，高い周波数を持つ局所 的な部分がクラックである可能性が高いことになる．更に，ク ラックは, 久けの深さも重要な特徴であるので, 振幅の大きさ も欠陥検出の条件となる，また，チップの辺上において，クラ ックの位置を特定することも重要な要件となる.

ウェーブレット変換は，波形の周波数と振幅の関係を解析で きるとともに，波形の中で信号が存在する時間を特定可能とい

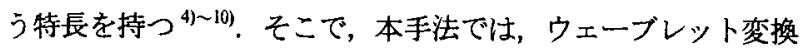
を用い，チップの各辺から得られたプロファイルを入力信号と して，周波数と振幅の関係からクラックを検出し，チップの辺 上におけるクラックの位置を特定する.

図 4 に処理過程を示寸. まず, 画像を 2 值化し, チップの 4 隅の位置情報に基づいて，各辺の凸凸状態を表すプロファイル を得る. 次に, プロファイルに対してウェーブレット変換を行 い，周波数と振幅に対してしきい值以上の信号部分をクラック として検出する. 以下に，各処理過程について説明する.

\section{1 画像の 2值化}

最初に, 画像の 2 値化を行う。チップの表面状態は, チップ

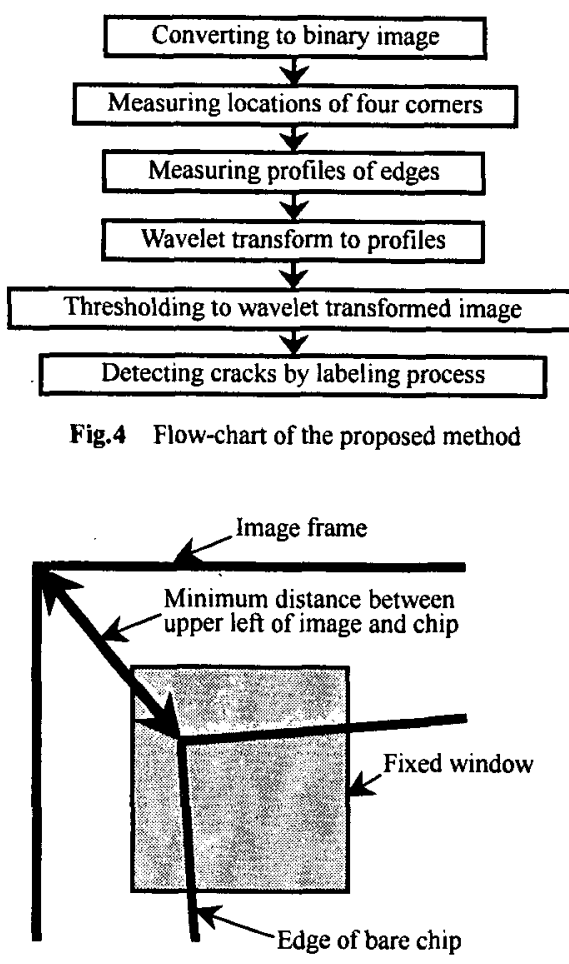

Fig.5 Extraction of the upper left corner of bare chip

の種類や状態によって変化し，画像のコントラストも影響を受 ける. 2 值化のしきい值として固定值を与えると,このコントラ ストの変化によって，エッジ部分の 2 值化状態がわずかに変化 するため, 安定な 2 值画像が得られるしきい值設定法を採用す

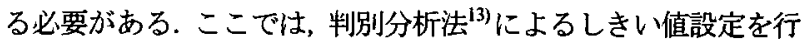
った. 判別分析法は，全画素の濃度分布ヒストグラムを 2 つの クラスに分離する場合，クラス内分散が最小に，かつクラス間 分散が最大となるようにしきい值を設定する手法であり，チッ プ表面の濃度変化に追従した安定な 2 值画像が得られる.

\section{2 チップ 4 檑の位置計測}

次に，画像内におけるチップの 4 隅の位置を計測する。これ は，チップの各辺に関する形状プロファイルを得るための前処 理となる. チップの左上隅を例とすると，図 5 に示すように, 画像の左上領域に設定した固定ウィン゙ドウ内に存在する白画素 の中で，画像の左上隅までのユークリッド距離が最小となる白 画素を求め，この位置をチップの左上隅とする. チップの他の 3 つの隅に関しても同様な処理によって位置を求める.

\section{3 チップの各辺のプロファイル計測}

チップの 4 隅の位置を基準として, チップの各辺の凸凸状態 を表す 1 次元のプロファイルを得る. ここでは, 例として, チ ップの上辺のプロファイルを求める処理について説明する. 図 6 に示すように，チップの左上隅と右上隅の座標を各々 $\left(x_{1}, y_{1}\right)$, $\left(x_{2}, y_{2}\right)$ とすると, チップの上辺の傾き $\theta$ を次式によって求める.

$$
\theta=\tan ^{-1} \frac{y_{1}-y_{2}}{x_{1}-x_{2}}
$$

次に，画像の上端に位置する各画素を始点として，図 6 に示寸 ように，チップの上辺の傾き $\theta$ に対して垂直方向に画素を順次 走查し，白画素が初めて発見された位置を求めていく．チップ の上辺全体に対してこの走査を行い，各走查線における白画素 の位置を 1 次元のプロファイルとする. 図7は，チップの上辺 


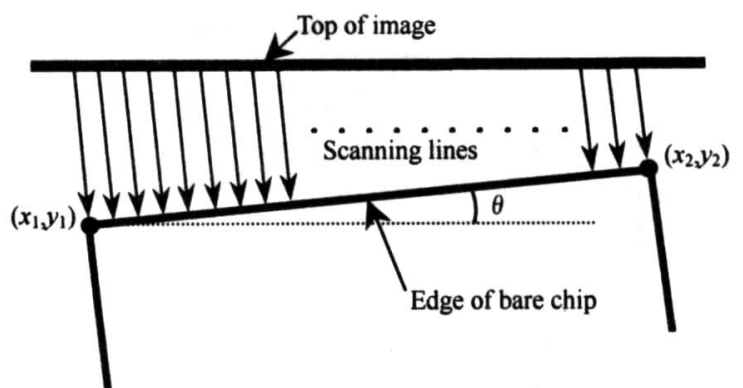

Fig.6 Measurement of profile of upper edge of bare chip

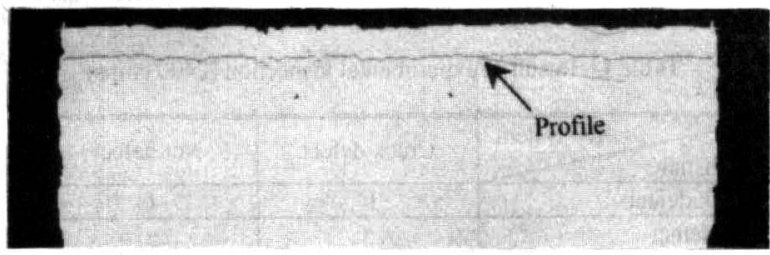

Fig.7 A measured edge profile

についてプロファイルを求めた例であり, チップの上辺のやや 下部にプロファイルが表示されている. 他の 3 辺に関しても, 同様な処理によってプロファイルを求める.

\section{4 ウェーブレット変換}

次に, チップの各辺に関するプロファイルを 1 次元の信号と とらえ, ウェーブレット変換を行う. ウェーブレット変換では, 時間的かつ周波数的に局在した関数として, マザーウェーブレ ット $\psi(t)$ を準備する. 信号 $x(t)$ に対するマザーウェーブレット $\psi(t)$ による畳み込み演算は，次式によって表される ${ }^{4)}$ (10).

$$
X(b)=\int_{-\infty}^{\infty} x(t) \cdot \psi(t-b) d t
$$

$X(b)$ は，信号 $x(t)$ からマザーウェーブレットによって時刻 $b$ 付近 の成分を抽出したものとなる. ここで, $b$ はシフト係数を表す. ウェーブレット変換では， $\psi(t)$ を時間軸および振幅方向に伸縮 させ, 各種の周波数に対応する関数を生成する. すなわち,

$$
\psi(t) \rightarrow \frac{1}{\sqrt{a}} \psi\left(\frac{t}{a}\right)
$$

とする. ここで, $a$ はスケーリング係数を表す. シフト係数 $b$ と スケーリング係数 $a$ を用いると, マザーウェーブレットは,

$$
\psi_{a, b}(t)=\frac{1}{\sqrt{a}} \psi\left(\frac{t-b}{a}\right)
$$

と表される. また, ウェーブレット変換は次のように表される.

$$
X(a, b)=\int_{-\infty}^{\infty} x(t) \cdot \psi_{a, b}(t) d t
$$

本手法では, ベアチップに発生するクラックと類似した形状 を持つ関数として, ガボール関数 ${ }^{5) ~ 10)}$ に着目し, 次式に示すガ ボール関数に基づくマザーウェーブレットを用(たた ${ }^{8) ~ 10) . ~}$

$$
\psi(t)=e^{i \omega t} \cdot e^{-t^{2} / 2}
$$

また,この場合, ガボールウェーブレットの振幅は,

$$
|X(a, b)|=\sqrt{\operatorname{Re}\{X(a, b)\}^{2}+\operatorname{Im}\{X(a, b)\}^{2}}
$$

により求められる.ここで, $\operatorname{Re}\{\}$ は実部, $\operatorname{Im}\{\}$ は虚部を表す.

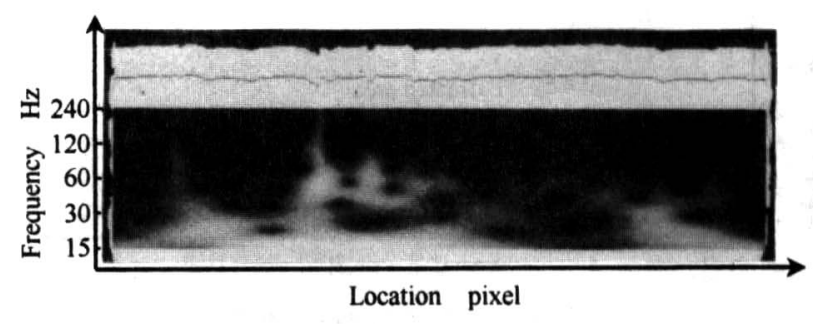

Fig.8 A sample of wavelet transformed image

本手法では，計算機を用いてウェーブレット変換を実行する ため, スケーリング係数 $a$ とシフト係数 $b$ の離散化が必要とな る. スケーリング係数 $a$ については, $a$ を離散化した結果得られ る, 隣接する各々の $a$ の值に関するマザーウェーブレットが同 形かつ等間隔のフィルタとなるように,

$$
a_{m}=a_{0}^{m} \quad\left(a_{0}: \text { 定数, } m: \text { 整数 }\right)
$$

と離散化する ${ }^{9100}$. この場合, 周波数を対数変換した軸に関して, スケーリング係数 $a$ が等間隔となる. 次に, シフト係数 $b$ につ いては, サンプリング定理を満たすように, 周波数帯域幅の 2 倍程度以内の範囲内で離散化を行う。ここでは, スケールによ らず一定のサンプリング間隔で離散化されるように,

$$
b_{n}=b_{0} \cdot n \quad\left(b_{0}: \text { 定数, } n: \text { 整数 }\right)
$$

と離散化を行う ${ }^{910)}$.

以上に述べたウェーブレット変換の結果, 横軸が時間, 縋軸 が周波数を表し，これらの軸による 2 次元座標值が振幅を表す 解析結果が得られる. 図 8 は, 図 7 に示したプロファイルに対 して, ウェーブレット変換を実行した結果を示す.ここでは, プロファイルの長さ, すなわちチップの辺長ほぼ 470 画素を 1 秒と考えて周波数を表している. 従って, ウェーブレット変換 の結果において, 横軸はチップ辺上の位置, 縌軸はプロファイ ルの局所的な周波数, 濃度はプロファイルの局所的な振幅を表 す. 図 8 では, 緹軸は $15 \mathrm{~Hz}$ から $240 \mathrm{~Hz}$ までの周波数を表してお り, これはプロファイルでは, ほぼ 32 画素から 2 画素の範囲を 意味する. また, 濃淡值は, 振幅を 0 (黒) から 255 (白) の範 囲で表しており，これはプロファイルでは，振幅が 0 画素から 12 画素の範囲となる.

\section{5 振幅と周波数による欠陥検出}

次に, ウェーブレット変換の結果に対して, 振幅と周波数に しきい值を設け, クラックを検出する. クラックは鋭いくさび 状であるため, 久け部分の深さと幅, すなわち, 振幅と周波数 の双方の特徵によって検出される. 振幅と周波数は相互に影響 を持つことも考えられるが, 目視によって検出されたクラック の振幅と周波数を解析した結果, 双方ともに固定のしきい值を 与えることによって, クラックを安定に検出できることがわか った. すなわち, ウェーブレット変換の結果に対して, ある振 幅以上の部分を抽出するために, 一定の浱度以上の領域を抽出 する 2 值化を行い, 次に, 高周波数領域だけを抽出するために, 図 9 に示寸ように, ある周波数末満の領域にマスクをかける.

ウェーブレット変換の結果に対して，しきい值処理を行った 結果は 2 值画像となる. 最後に, ラベリング処理によって白領 域を抽出し, それらの重心位置からチップの辺上におけるクラ ックの位置を特定する. ラベルが発見されない場合は, その辺 上にはクラックが存在しないことを意味する. 図 10 は, ウェー ブレット変換の結果をしきい值処理によって 2 值化した後, ラ ベリング処理によってクラックを検出した最終結果例を示す. 


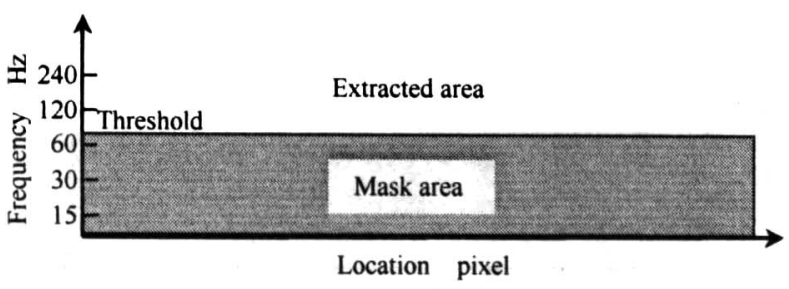

Fig.9 Extraction of high frequency area

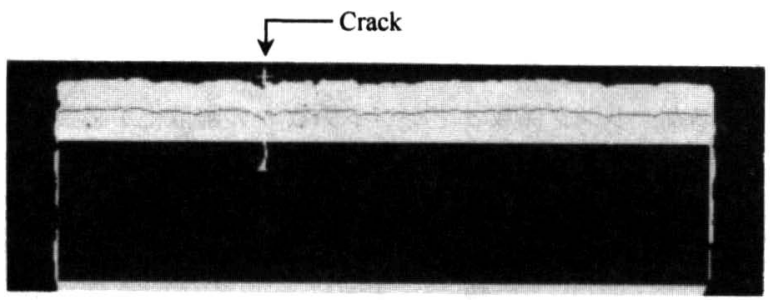

Fig.10 A detected crack

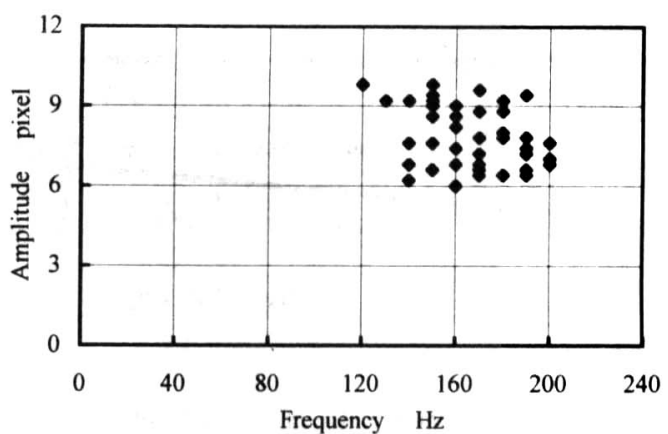

Fig.11 Limits of thresholds for width and frequency to detect cracks

Table 1 Result of experimental inspection (2400 chips)

\begin{tabular}{l|c|c}
\hline By visual & Crack defect & Not defect \\
\hline Crack defect & 34 & 0 \\
\hline Not defect & 5 & - \\
\hline
\end{tabular}
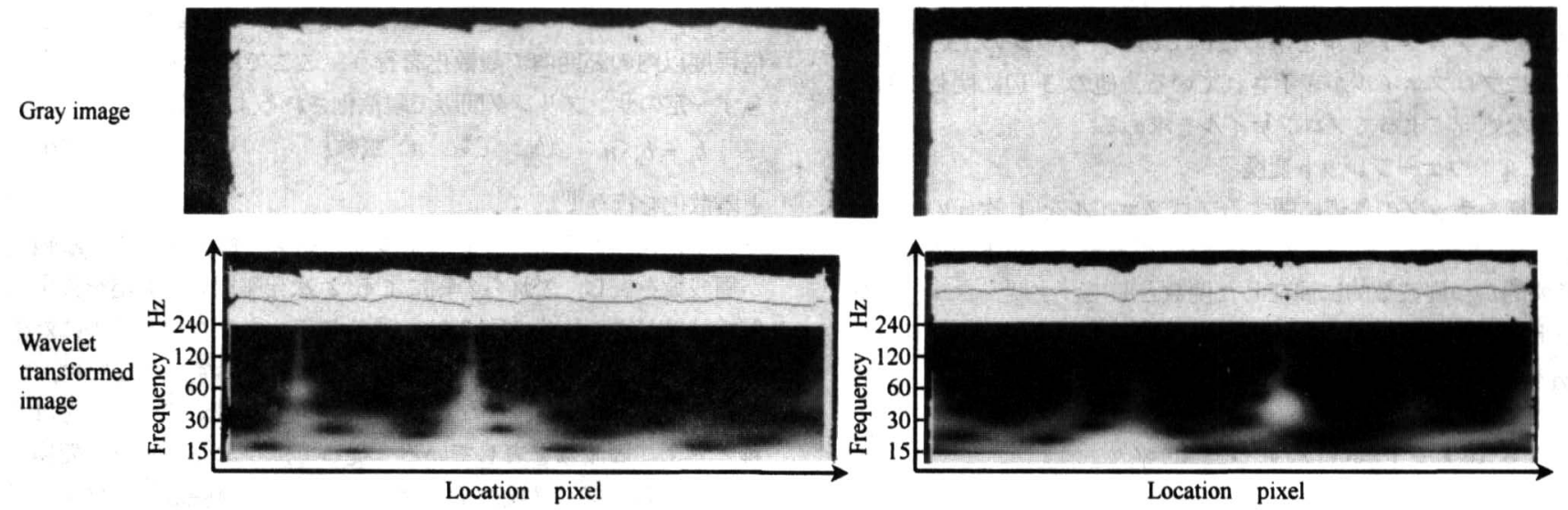

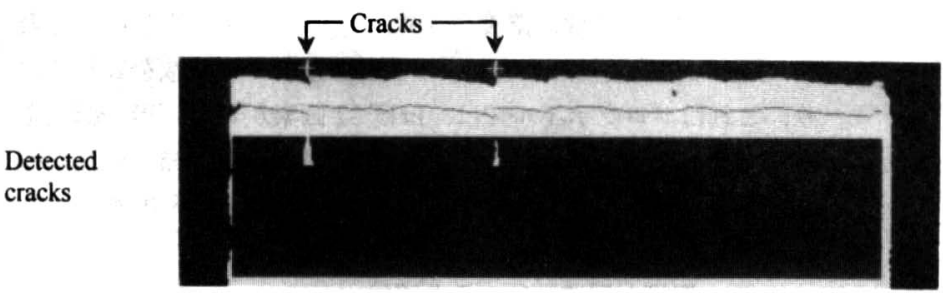

(a) Side 1

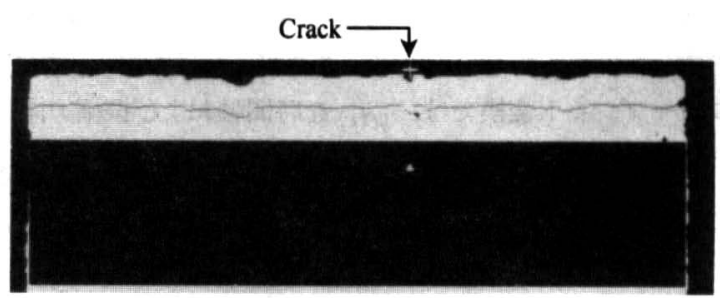

(b) Side 2

Fig.12 Processes to detect cracks

\section{5. 実験と結果}

本手法を用いて, ベアチップのクラックを検出した実験結果 について述べる. ウェーブレット変換におけるパラメータは, 予備実験の結果, 式 (6) の $\omega=5$, 式 (8) の $a_{0}=2^{1 / 24}$, 式 (9) の $b_{0}=1$ と設定した.

\section{1 しきい值の設定}

まず，ウェーブレット変換の結果において，クラックを検出 するために設定する振幅と周波数に関するしきい值について述 ベる，検査員の目視によって検出されたクラックの中から代表 的なものを 50 個サンプリングして，各々のクラックを本手法に よって検出するために, ウェーブレット変換の結果に対して設 定すべき振幅と周波数に関するしきい值の限界値を求めた．図 11 に結果を示すが，振幅に関する検出の限界値として 6 画素, 周波数に関する検出の限界值として $120 \mathrm{~Hz}$ を設定した場合，す
べてのクラックを検出することができた．次に，ここで得られ た振幅と周波数の限界值を本手法におけるクラック検出のため のしきい值として設定し, サンプリングした 50 個のクラックを 含む計 46 個のベアチップについて，各辺上のプロファイルを用 いて久陥検出実験を行った結果, 実際のクラック以外の部分は 検出されなかった. つまり, サンプルのクラックを検出するた めに設定した振幅と周波数に関するしきい值によって, サンプ ルのベアチップにおけるクラックとクラック以外の凹凸部分を 識別することが可能であった.

一般的に, 欠陥検出のためのしきい值は, 厳しく設定すると, 非欠陥を欠陥と判定する虚報が増大するが，ここでは，欠陥の 検出漏れを極力抑えることを戦略として，振幅に関するしきい 値には, 実験によって求められた値よりも若干厳しい值として, 5 画素以上の場合にクラックと判定することにした. また, 周波 数に関するしきい值は, 実験值と同様に $120 \mathrm{~Hz}$ 以上とした。 

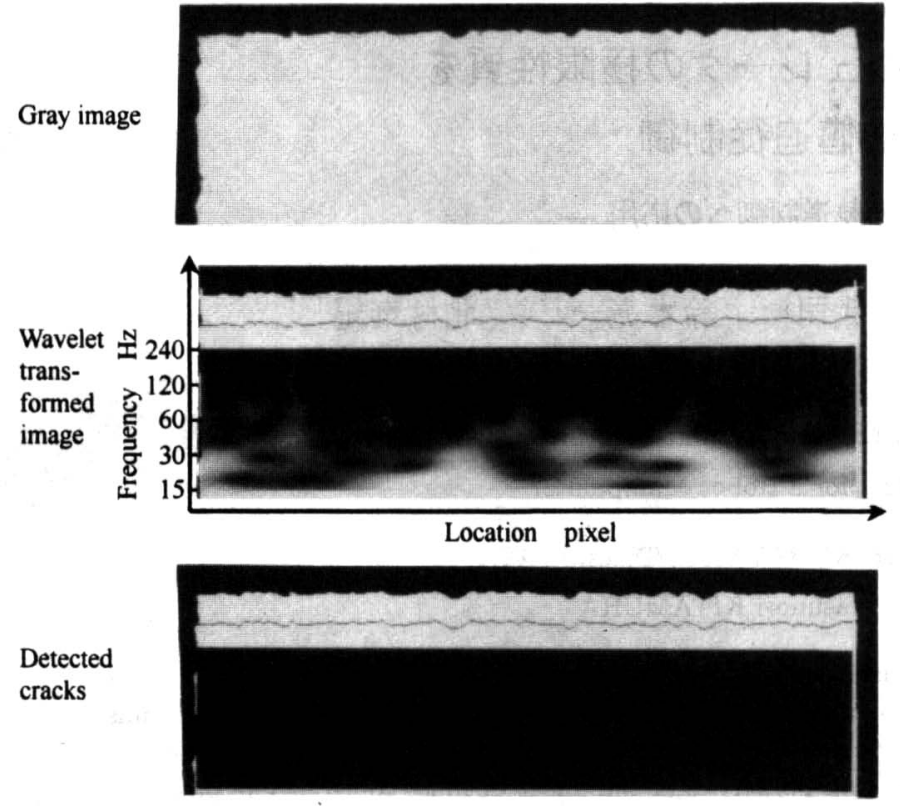

Fig.13 Processes when cracks are not included

\section{2 欠陷検出結果}

次に, 2400 個のベアチップについて, 本手法を用いた検査シ ステムによってクラックの検出実験を行った. これらのチップ は目視によっても検查され, 双方の検査結果の整合性を評価し た. 結果を表 1 に示寸. 目視検査の結果, クラックと判定され た部分が 34 か所あったが，これらは検査システムによってもす ベてクラックとして検出された. 従って, 久陷の検出漏れは皆 無であった. 逆に, 検査システムによってクラックとして検出 された部分は 39 か所であり，差分の 5 か所が虚報となった．虚 報が若干発生している理由としては，しきい值をやや厳しく設 定していることが考えられるが，欠陷の検出漏れを抑えるため には, ほほ妥当なしきい值設定と考えられる. つまり，少数の 虚報が発生しても，すべてのベアチップを目視検査する労力と 比較すれば，検査システムによって欠陥として検出された部分 だけを目視によって再検查すればよいため，検査作業の大幅な 省力化が可能と考えられる.

図 12 は, ベアチップ原画像, プロファイルに対するウェーブ レット変換の結果, およびクラックを検出した結果を示す.こ こに示した例は, チップの上辺以外の部分も含まれるが, すべ て画像を回転させて表示している. また, 図 13 はクラックが含 まれない場合の例を示している.

\section{3 処理時間}

本手法によってべアチップ 1 個を検査するのに要する時間は, 処理系に PentiumIII-450MHz を用い，0.52 秒であった. 処理時間 の内訳を表 2 に示す. 前処理となる画像の 2 值化, チップの姿 勢計測, プロファイル計測, および後処理となるしきい值処理 とラベリングと比較して, ウェーブレット変換に要する時間が 全体の $80 \%$ 程度を占めている. 本手法では, 特にウェーブレッ ト変換を高速化するための工夫を行っていないが, 検査時間を より短縮化するためには, 高速フーリエ変換と同様な高速化手 法等 $^{10)}$ を採用することが有効と考えられる.

\section{4 従来手法との比較}

従来から, 電子部品の欠損検出などに用いられている膨張と 縮退処理 ${ }^{11) 12)}$ をクラック検出に適用することを試みた. 図 14 は,
Table 2 Contents of processing time (s)

\begin{tabular}{l|c}
\hline \multicolumn{1}{c|}{ Process } & Processing time \\
\hline Converting to binary image & 0.01 \\
Measuring locations of corners & 0.01 \\
Measuring edge profiles & 0.03 \\
Wavelet transform to profiles & 0.42 \\
Thresholding to wavelet image & 0.02 \\
Detecting cracks by labeling & 0.03 \\
\hline Total & 0.52 \\
\hline
\end{tabular}

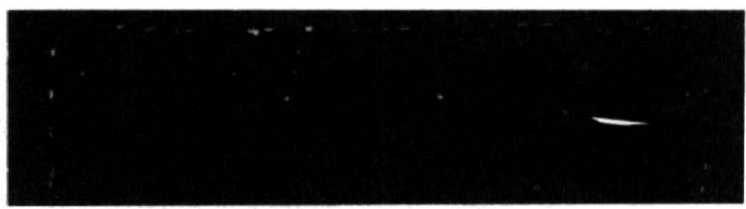

Fig.14 A result by dilation and erosion

ベアチップ画像を 2 值化した後, 膨張処理 2 回と縮退処理 2 回 を施した結果例を示す.ここで例に示したチップは, 図 10 に示 したものと同一であり, チップの上辺部分だけを提示している. この結果から，膨張と縮退処理によっては，クラックを周囲に 存在するエッジの凹凸部分と分離し, 形状特徽に基づいて非欠 陥部分と明確に識別することは困難と考えられる.

\section{6. 結 論}

ウェーブレット変換と画像処理を用い, 半導体ベアチップの エッジ部分に発生するクラックを検出する手法を提案した. チ ップの 4 隅の位置を基準として, チップの辺上の 1 次元プロフ アイルを求め, ウェーブレット変換を行う. そして, 振幅と周 波数に関するしきい值処理によって，クラックを検出する．実 験の結果, 以下のことがわかった。

(1) 2400 個のベアチップについて, 100\%の検出率を記録した.

(2) 欠陥検出のためのしきい值をやや厳しく設定しているた め，若干の虚報が発生している.

(3) 検査に要する処理時間はチップあたり 0.52 秒となった.

今後の課題としては, 虚報数を削減するために, しきい值を 微調整すること, および処理時間の短縮化が挙げられる.

\section{参 考 文 献}

1) 塚田 裕：ビルドアップ配線板入門，日刊工業新聞社 (1998) 23.

2) 斉藤文彦 : フリップチップ実装における濃淡画像処理による部品位 置決め手法, 精密工学会誌, 63, 3(1997) 381.

3) 菊地正典: 半導体のすべて，日本実業出版社，(1998) 141.

4) 榊原 進, 清水信行 : ウェーブレットによる非定常データ解析の新 展開, 日本機械学会誌, 99, 931 (1996) 437.

5) チャールズ K.チュウイ (桜井 明, 新井 勉 訳) : ウェーブレッ 卜入門, 東京電機大学出版局, (1993) 59.

6) 榊原 進: ウェーブレットビキナーズガイド, 東京電機大学出版局, (1995) 2 .

7) 佐藤雅昭 : ウェーブレット理論の数学的基礎 第 I 部, 日本音響学 会誌, 47, 6(1991) 405 .

8) R.Kronland-Marttinet, J.Morlet and A.Grossmann: Analysis of Sound Patterns through Wavelet Transforms, Int. J. Pattern Recognition Artif. Intell., I (1987) 273.

9) 河原英紀 : ウェーブレット解析の聴覚研究への応用, 日本音響学会 誌, 47, $6(1991) 424$

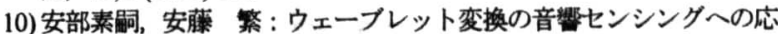
用, インターフェイス, 21, 2(1995) 137.

11) 尾上守夫 : 画像処理ハンドブック，昭晃堂, (1987) 315 .

12)安居院 猛, 長尾智晴: 画像の処理と認識, 昭晃堂, (1992) 63.

13) 大津展之: 判別および最小 2 乗規準に基つくく自動しきい值選定法, 電子情報通信学会論文誌, 63-D, 4 (1985) 933. 